\title{
INFECTIOUS JUMP SKILLS
}

\author{
Herli Pardilla ${ }^{1}$, Mulyana ${ }^{2}$, Achmad Sofyan Hanif ${ }^{3}$ \\ State University of Jakarta \\ herlipardilla@gmail.com ${ }^{1}$ \\ Mulyana.unj@unj.ac.id ${ }^{2}$ \\ Sofyanhanif.unj@unj.ac.id ${ }^{3}$
}

\begin{abstract}
The aim of this research is to know the difference of learning method which consists of learning method part (A1), overall method (A2) and combination method (A3) with moderator of motor ability in improving skill. The experiment was conducted by using $2 \times 3$ factorial experimental method with population which used as target population. The research was student of Physical Education University of Riau Force 2016/2017 as many as 134 which consist of 89 son and 45 daughter. Sampling was done by selecting $27 \%$ of the highest score data and $27 \%$ lowest score. Result of hypothesis test 1) difference between group of method part (A1) with group of whole method (A2) equal to t0 $(A 1 \times A 2)=-1,699, p$-value $=0,096 / 2=0,048<0,05$, mean h0 rejected. 2$)$ the difference between the part method group $(A 1)$ and the combination method group $(A 3)$, worth tO $(A 1 x A 3)=-$ 3.490, $p$-value $=0.001 / 2=0.0005<0.05$, h0 is rejected. 3) the difference between the whole method group (A2) and the combination method group (A3) worth t0 $(A 2 x A 3)=-1.791, p$-value $=0.080 / 2=$ $0.040<0.05$, h0 is rejected. 4) Influence Interaction (Interaction Effect) $F o(A B)=34,349$ with $p$ value $=0,000<0,05$ or $\mathrm{HO}$ is rejected. This means there is a very significant interaction effect. 5) Differences in skill jump results between high motor and high-motor (A1B1 - A2B1) methods were 3.496 , $p$-value $=0.001 / 2=0.0005<0.05$ or H0 rejected. 6) Differences in skill jump results between high motor part and high motor combination method $(A 1 B 1-A 3 B 1)$ worth $=9.568$, $p$-value $=0,000$ / $2=0,000<0.05$ or $\mathrm{HO}$ is rejected. 7) Differences in skill jump results between the overall method with high motor and high motor combination method $(A 2 B 1-A 3 B 1)$ worth $=6,072, p$-value $=0.002 \mathrm{I}$ $2=0.001<0.05$ or $H O$ is rejected. 8) The difference in the results of the jump skill between the part method with the low motor and the overall method with low motor $(A 1 B 2-A 2 B 2)$ worth $=0.286$, $p$ value $=0.680 / 2=0.34>0.05$ or HO is accepted thus, no there are differences. 9) Differences in skipjack skill results between the low-motor part and low motor combination method (A1B2 - A3B2) $=-1,800$, $p$-value $=0.079 / 2=0.0395<0.05$ or HO is rejected .10$)$ Differences in skill jump results between overall and low motor methods and low motorized combination methods $(A 2 B 2-A 3 B 2)=-$ 2.086, $p$-value $=0.043 / 2=0.0215<0.05$ or $\mathrm{HO}$ is rejected. difference.
\end{abstract}

Keywords: infectious jump skills, learning methods and motor skills

Exercise is one of the activities that human beings do to achieve healthy and fit physical condition. But over time and technological developments nowadays there is a change or shifting purpose and function of a person doing sports activities. Indeed sport aims to improve the quality of human resources, so the government makes sport as a means of National Development. Attempts to achieve sports achievement are done in the form of training and teaching and learning process as well as sports activities. The learning process or the exercises given should be oriented towards the goals to be achieved and expressed by the change in behavior that is comprehensive. Such skills can only be possessed through a process of motion learning. In line with that to determine the quality and quantity of motion is not apart also on the basic motion components that support it are: road, run, jump, and throw. 
Athletic exercise is one of the branches that are competed or contested which consists of the numbers namely: road, running, jumping and throwing. In the jump category one of them is the athletic jump branch. In this case, jumping up is also an athletic number taught at the college level with basic engineering elements consisting of prefix, pedestal, hovering in the air and landing. Jump is the desire to reach the horizontal jump distance as far as possible by using three successive jumps, the race rules specify that the support for every first step of the two hop and step should be done on the same leg while the third step (jump) should be done with different legs / opposite. According to Joseph L. Rogers (2000, p.159) jumping is a unique event that requires a combination of speed, strength, and balance. It consists of three different stages that must flow into each other. That is a hop (take off and land on the same leg), step (landing on the opposite leg), and jump (done like a lot on the long jump).

To be able to perform well in the jump, there are several aspects of motor skills that must be considered, namely strength, explosive power, flexibility, coordination, speed, balance, agility, flexibility, etc. In general, this motor ability can be defined as the motion of the individual in the motion, both motion that is not motion sports or motion in sports or maturity appearance motor ability. Mastery techniques jump movement through motor skills learners can learn from step by step so that become skilled in the movement. Learners who can master basic techniques skillfully and competently in this movement will support the development of self-confidence and a sense of spirit in the process of learning and training.

Furthermore, to support the learning process at jumping athletes, it is necessary to develop the appropriate teaching and learning process so that the learning objectives of athletic jump skills can be achieved optimally. Learning is a system, consisting of various components that are interconnected with one another, these components include: objectives, materials, methods, and evaluation. To cultivate the ability and skill of basic jump skill technique for students, it is necessary to have proper teaching method in teaching. The more precise the method of learning that the educator chooses, the more mastering the basic jump technique, so that the students will be skilled in the implementation of the jump jumping movement. Learning method that is assumed by researchers to boost jump skill with three method that is: part learning method, whole learning method, and combination learning method.

Method part is a gift of learning material from the special to the public. motion tasks are learned and trained part by part. according to Martin P. Schwelnus (2008, p.37) also stated "While part practice occurs when the various components of the skill are learned thoroughly first". Usually this method is applied if the structure of the motion is quite complex so it is estimated by studying part by part it will give optimal results. In this jump learning educators divide the exercise according to the basic technique that is at the time of the prefix, when tipped, stepping and jumping approach section of the method section before given the experience of the jump process intact. This means that after students learn and master the parts of a motion activity in the jump, then the subsequent parts are classified again into a complete and comprehensive activity.

While the whole learning method is a way of giving the material from general to special. According Yunyun Yudiana (2008, p331) states that the whole teaching method is implemented to master a series of movements, to athletes are taught the movement as a whole at once and practiced as a whole as well. One such example in teaching motion skills or jumping skill, then the whole or whole shape is taught first and then broken into pieces.

And the last is a combination learning method, a combination learning method is a combined method of the overall method and part method, with the intention of combining the part-overall method. According to Schwellnus (2008, p. 37) The whole-part-whole practice model is an extension of both the whole and part practice methods. In the whole-part-whole model, the subject is provided with the skill in its entirety before having it broken down into parts and taught using the segmentation, 
simplification, or fractionation methods. In the combination method the subject is taught with the overall skills and broken down into parts and taught using segmentation, simplification.

\section{METHOD}

The research method used in this study is the method of experimenting or giving treatment to students. This study consists of independent variables, moderator variables and dependent variables. The independent variable (learning method) consists of 3 methods, namely: part, whole and combination. The moderator variable (motor ability) consists of 2 parts, namely: high motor skills and low motor skills and while the dependent variable is the infectious jump skill. The design used in this study is the design of the Factorial $3 \times 2$ experiment which was adopted from the opinion of Kenneth S. Bordens and Bruce B. Abbott (2014, p.315).

\section{X 3 Factorial Treatment Design}

\begin{tabular}{|l|l|l|l|}
\hline \multirow{2}{*}{$\begin{array}{c}\text { B } \\
\text { (Motor ability) }\end{array}$} & \multicolumn{3}{|c|}{$\begin{array}{c}\text { A } \\
\text { (Learning methods) }\end{array}$} \\
\cline { 2 - 4 } & $\mathrm{A}_{1}$ & $\mathrm{~A}_{2}$ & $\mathrm{~A}_{3}$ \\
\hline $\mathrm{B}_{1}$ & $\mathrm{~A}_{1} \mathrm{~B}_{1}$ & $\mathrm{~A}_{2} \mathrm{~B}_{1}$ & $\mathrm{~A}_{3} \mathrm{~B}_{1}$ \\
\hline $\mathrm{B}_{2}$ & $\mathrm{~A}_{1} \mathrm{~B}_{2}$ & $\mathrm{~A}_{2} \mathrm{~B}_{2}$ & $\mathrm{~A}_{3} \mathrm{~B}_{2}$ \\
\hline
\end{tabular}

Information:

A1 $=$ Learning Methods Section

A2 = Overall Learning Method

A3 $=$ Combination Learning Method

B1 = High Motor Capability

B2 = Low Motor Ability

The population in this study is in the category of students of class of 2015/2016 and 2016/2017 semester 2 (even) who have attended the athletic jumping lecture program in Physical Education Faculty of Teacher Training and Education University of Riau as many as 134 which consists of 89 sons and 45 daughters. Sampling is done by purposive sampling technique with reference to Verducci theory that is selecting $27 \%$ of the highest score data and $27 \%$ lowest score.

In accordance with the types of variables involved in the research, to obtain the data processed in this study, the instruments used are (1) Jump instrument by measuring (product) that is the result of leap and assess (process) that is skill of jump skills , (2) Furthermore, to measure the height of motor ability / Motor Ability (Barrow 1959; Scot 1939) the student is using Motor Ability Test consisting of, Sprint $30 \mathrm{~m}$, Standing Broad Jump (SBJ), Standing Triple Jump (STJ) / Triple jump, Overhead back (OHB) toss with a shot off a toe board $(7.3 \mathrm{~kg})$ for men, Sprint $150 \mathrm{~m}$ : One 150meter sprint on a track, Shutle Run and Sit and Reach. Based on the explanations and descriptions that have been stated previously the data analysis techniques in this study consists of data descriptions, testing requirements analysis using the test of normality and homogeneity and hypothesis testing. The data obtained in this study were processed and analyzed by using two way analysis of variance (ANAVA) technique with $3 \times 2$ Factorial design using SPss version 17 while the test standard was done at the alpha significance level of 0.05 . Then proceed with the Dunnet-t test, because there is an interaction between the learning method and motor skills to the jump skill.

\section{Normality Test}

\section{RESULTS AND DISCUSSION}

Normality test is useful to determine the data that has been collected normally distributed or taken from a normal population. 
To see whether the data obtained from each research variable is normal or not, normality testing is performed using the Liliefors test. If the result of the highest L count (L0) price from the group of variables examined is smaller than $\mathrm{L}$ table $(\mathrm{Lt})$ in the list of liliefors tables, then the data is said to be normally distributed.

\section{a. Intergroup Normality Test Results Treatment A}

Table.2. Descriptive Test Results Group Normality A

\begin{tabular}{|c|c|c|c|}
\hline \multirow{2}{*}{ No } & $\mathbf{A} 1$ & $\mathbf{A} 2$ & $\mathbf{A} 3$ \\
\cline { 2 - 4 } & $\mathrm{F}(\mathrm{Zi})$-S(Zi) $\mid$ & $\mathrm{F}(\mathrm{Zi})-\mathrm{S}(\mathrm{Zi}) \mid$ & $\mathrm{F}(\mathrm{Zi})$-S(Zi) \\
\hline 1 & 0,0695 & 0,0296 & 0,0446 \\
\hline 2 & 0,0303 & 0,0062 & 0,0204 \\
\hline 3 & 0,0596 & 0,0565 & 0,0412 \\
\hline 4 & 0,0425 & 0,0759 & 0,1559 \\
\hline 5 & 0,0415 & 0,0360 & 0,0684 \\
\hline 6 & 0,0167 & 0,0058 & 0,1525 \\
\hline 7 & 0,0185 & 0,0744 & 0,0003 \\
\hline 8 & 0,0314 & 0,0954 & 0,0756 \\
\hline 9 & 0,0616 & 0,0329 & 0,0267 \\
\hline 10 & 0,0859 & 0,0848 & 0,0037 \\
\hline 11 & 0,0634 & 0,1104 & 0,0455 \\
\hline 12 & 0,0837 & 0,0430 & 0,0467 \\
\hline 13 & 0,0212 & 0,0361 & 0,0420 \\
\hline 14 & 0,1217 & 0,1544 & 0,0969 \\
\hline 15 & 0,0221 & 0,0602 & 0,0106 \\
\hline 16 & 0,0786 & 0,0202 & 0,0345 \\
\hline \hline Lo & 0,1217 & 0,1544 & 0,1559 \\
\hline Ltabel & 0.213 & 0.213 & 0.213 \\
\hline
\end{tabular}

b. Normality Test Between Learning Group Learning Method (A) with Motor Capability (B).

Table.3. Descriptive Test Results Normality of Groups A and B

\begin{tabular}{|c|c|c|c|c|c|c|}
\hline \multirow{2}{*}{ No } & A1B1 & A2B1 & A3B1 & A1B2 & A2B2 & A3B2 \\
\cline { 2 - 7 } & $|F(Z i)-S(Z i)|$ & $|F(Z i)-S(Z i)|$ & $|F(Z i)-S(Z i)|$ & $|F(Z i)-S(Z i)|$ & $|F(Z i)-S(Z i)|$ & $|F(Z i)-S(Z i)|$ \\
\hline 1 & 0,0226 & 0,0720 & 0,1042 & 0,0950 & 0,0051 & 0,0337 \\
\hline 2 & 0,1027 & 0,0465 & 0,1404 & 0,0719 & 0,0957 & 0,0134 \\
\hline 3 & 0,1480 & 0,0367 & 0,0502 & 0,0001 & 0,1577 & 0,0369 \\
\hline 4 & 0,2233 & 0,0883 & 0,0183 & 0,0687 & 0,2340 & 0,1106 \\
\hline 5 & 0,1479 & 0,1363 & 0,0711 & 0,1827 & 0,0854 & 0,2091 \\
\hline 6 & 0,0773 & 0,0359 & 0,1749 & 0,0286 & 0,0357 & 0,2361 \\
\hline 7 & 0,0411 & 0,1250 & 0,1431 & 0,0487 & 0,0597 & 0,0118 \\
\hline 8 & 0,1597 & 0,0464 & 0,0648 & 0,1014 & 0,0875 & 0,0430 \\
\hline \hline Lo & 0,2233 & 0,1363 & 0,1749 & 0,1827 & 0,2340 & 0,2361 \\
\hline Ltabel & 0.285 & 0.285 & 0.285 & 0.285 & 0.285 & 0.285 \\
\hline
\end{tabular}

\section{Homogeneity Test Result}

Table.4. Homogeneity Test Results

\begin{tabular}{|c|c|c|c|}
\hline \multicolumn{4}{|c|}{$\begin{array}{l}\text { Levene's Test of Equality of Error } \\
\text { Variances } \\
\text { a }\end{array}$} \\
\hline $\mathrm{F}$ & $\mathrm{df1}$ & $\mathrm{df} 2$ & Sig. \\
\hline .923 & 5 & 42 & .475 \\
\hline \multicolumn{4}{|c|}{$\begin{array}{l}\text { Tests the null hypothesis that the error } \\
\text { variance of the dependent variable is } \\
\text { equal across groups. } \\
\text { a. Design: Intercept }+A+B+A{ }^{*} B\end{array}$} \\
\hline
\end{tabular}

From the table analysis of variance analysis using the Levene's Test above there is a price of the leven's test with statistics $F=0.923$ with $\mathrm{db}=5$ and $\mathrm{db}=42$ at $\mathrm{p}$-value $=0.475>0.05$. So that the data for the 6 groups of sample data have the same variant or Homogen. 


\section{Hypothesis Test Results}

Based on testing the hypothesis and the influence of learning methods and motor skills on the results of the outbreak jump skills that have been done, it can be seen in the table below:

Table 5: Contrass Test of Skill Jump Skill Value between treatment groups Motoric Ability Learning Methods

\begin{tabular}{|c|c|c|c|c|c|c|c|}
\hline \multicolumn{8}{|c|}{ Contrast Tests } \\
\hline & & Contrast & $\begin{array}{l}\text { Value of } \\
\text { Contrast }\end{array}$ & Std. Error & $t$ & $\mathrm{df}$ & Sig. (2-tailed) \\
\hline \multirow{18}{*}{$\begin{array}{l}\text { Keterampilan Lompat } \\
\text { Jangkit }\end{array}$} & \multirow[t]{9}{*}{ Assume equal variances } & $\mathrm{A} 1 \mathrm{~B} 1 \mathrm{XA2B} 1$ & 6.8188 & 1.95068 & 3.496 & 42 & .001 \\
\hline & & $\mathrm{A} 1 \mathrm{~B} 1 \times \mathrm{A} 3 \mathrm{~B} 1$ & 18.6638 & 1.95068 & 9.568 & 42 & .000 \\
\hline & & $\mathrm{A} 2 \mathrm{~B} 1 \mathrm{XA3B} 1$ & 11.8450 & 1.95068 & 6.072 & 42 & .000 \\
\hline & & $\mathrm{A} 1 \mathrm{~B} 2 \times \mathrm{A} 2 \mathrm{~B} 2$ & .5588 & 1.95068 & .286 & 42 & .776 \\
\hline & & A1B2 XA3B2 & -3.5112 & 1.95068 & -1.800 & 42 & .079 \\
\hline & & $\mathrm{A} 2 \mathrm{~B} 2 \times \mathrm{A} 3 \mathrm{~B} 2$ & -4.0700 & 1.95068 & -2.086 & 42 & .043 \\
\hline & & A1B1 XA1B2 & 10.4825 & 1.95068 & 5.374 & 42 & .000 \\
\hline & & $\mathrm{A} 2 \mathrm{~B} 1 \mathrm{XA2B} 2$ & 4.2225 & 1.95068 & 2.165 & 42 & .036 \\
\hline & & A3B1 XA3B2 & -11.6925 & 1.95068 & -5.994 & 42 & .000 \\
\hline & \multirow{9}{*}{$\begin{array}{l}\text { Does not assume equal } \\
\text { variances }\end{array}$} & A1B1 XA2B1 & 6.8188 & 2.13733 & 3.190 & 13.931 & 007 \\
\hline & & $\mathrm{A} 1 \mathrm{~B} 1 \mathrm{X} \mathrm{A} 3 \mathrm{~B} 1$ & 18.6638 & 1.80010 & 10.368 & 12.768 & .000 \\
\hline & & A2B1 XA3B1 & 11.8450 & 1.88722 & 6.276 & 12.292 & .000 \\
\hline & & $\mathrm{A} 1 \mathrm{~B} 2 \times \mathrm{A} 2 \mathrm{~B} 2$ & .5588 & 1.95114 & .286 & 13.867 & .779 \\
\hline & & $\mathrm{A} 1 \mathrm{~B} 2 \times \mathrm{A} 3 \mathrm{~B} 2$ & -3.5112 & 1.90806 & -1.840 & 13.955 & .087 \\
\hline & & $\mathrm{A} 2 \mathrm{~B} 2 \times \mathrm{A} 3 \mathrm{~B} 2$ & -4.0700 & 2.00325 & -2.032 & 13.976 & .062 \\
\hline & & $\mathrm{A} 1 \mathrm{~B} 1 \mathrm{XA1B} 2$ & 10.4825 & 1.95979 & 5.349 & 13.845 & .000 \\
\hline & & $\mathrm{A} 2 \mathrm{~B} 1 \mathrm{XA2B} 2$ & 4.2225 & 2.12940 & 1.983 & 13.915 & .067 \\
\hline & & $\mathrm{A} 3 \mathrm{~B} 1 \mathrm{XA3B} 2$ & -11.6925 & 1.74364 & -6.706 & 13.080 & .000 \\
\hline
\end{tabular}

a. First Hypothesis: Differences Between Group Methods Section (A1) With Group of Overall Methods (A2).

The contrast of the table above can be analyzed, namely the price of t0 $(\mathrm{A} 1 \mathrm{xA} 2)=-$ $1,699, \mathrm{p}$-value $=0,096 / 2=0,048<0,05$, meaning that $\mathrm{H} 0$ is rejected. Thus, the jumping skill of the group is taught by the higher part method than the group given the whole method.

b. Second Hypothesis: Differences Between Group Methods Section (A1) With Groups of Combination Methods (A3).

In contrast $(\mathrm{A} 1 \mathrm{xA} 3)$ can be analyzed that the price of $\mathrm{t} 0(\mathrm{~A} 1 \mathrm{xA} 3)=-3,490, \mathrm{p}$-value $=$ $0,001 / 2=0,0005<0,05, \mathrm{H} 0$ is rejected. Thus, the jump skill of the group is taught by the higher part method than the group given the combination method.

c. Third Hypothesis: Differences Between Groups Overall Method (A2) With Combination Method Group (A3).

Then in the third hypothesis, the contrast table (A2xA3) can be analyzed, namely the price of t0 $(\mathrm{A} 2 \mathrm{xA} 3)=-1,791, \mathrm{p}$-value $=0,080 / 2=0,040<0,05, \mathrm{H} 0$ is rejected. Thus, the jumping skill of the group taught by the overall method is higher than in the group given the combination method.

\section{d. Fourth Hypothesis: Interaction Effect}

Fo $(A B)=34,349$ with $p$-value $=0,000<0,05$ or $\mathrm{H} 0$ is rejected. This means there is a very significant interaction effect between factor A (learning method) and factor B (motor ability) on skill jump skill in the student. It can be seen from the result of analysis that the influence of learning method variable and motor ability on skill jump ability is RSquared = $0,704 \times 100=70,40 \%$. 
e. Fifth Hypothesis: Differences in skill jump results between high-motor and high-motor part methods (A1B1-A2B1).

The difference between groups t0 $(\mathrm{A} 1 \mathrm{~B} 1-\mathrm{A} 2 \mathrm{~B} 1)=3.496, \mathrm{p}$-value $=0.001 / 2=0.0005$ $<0.05$ or H0 is rejected. Thus, the average group of students taught by the section method is higher than in the group of students who were taught by the whole method for high-skilled students.

f. Sixth Hypothesis: Differences in skill jump results between high-motor and highmotorized parts (A1B1-A3B1).

The difference between groups t0 $(\mathrm{A} 1 \mathrm{~B} 1-\mathrm{A} 3 \mathrm{~B} 1)=9.568, \mathrm{p}$-value $=0,000 / 2=0,000$ $<0.05$ or $\mathrm{HO}$ is rejected. Thus, the average group of students taught by the section method is higher than the group of students who were taught by a combination method for a group of highly skilled motor students.

g. The Seventh Hypothesis: The difference in skill jump results between the overall method with high motor and high motor combination method (A2B1 - A3B1).

The difference between groups t0 $(\mathrm{A} 2 \mathrm{~B} 1-\mathrm{A} 3 \mathrm{~B} 1)=6.072, \mathrm{p}$-value $=0.002 / 2=0.001$ $<0.05$ or $\mathrm{H} 0$ is rejected. Thus, the average group of students taught by the overall method is higher than the group of students who were taught by a combination method for a group of highly skilled motor students.

h. Eighth Hypothesis: Differences in skipjack skill results between the low motor part method and the low motor overall method (A1B2 - A2B2).

The difference between groups t0 $(\mathrm{A} 1 \mathrm{~B} 2-\mathrm{A} 2 \mathrm{~B} 2)=0.286, \mathrm{p}$-value $=0.680 / 2=0.34>$ 0.05 or $\mathrm{H} 0$ is accepted. Thus, there is no difference in the average group of students taught by the section method with the student group taught by the whole method in the group of students with low motor skills.

i. Ninth Hypothesis: Differences in the results of the transmission jump skills between the part method with the low motor and the combination method with the low motor (A1B2 A3B2).

The difference between groups t0 (A1B2 - A3B2) $=-1,800, p$-value $=0,079 / 2=0,0395$ $<0,05$ or $\mathrm{H} 0$ rejected means that there is an average difference between groups A1B2 - A3B2. Furthermore, the average value of the method group part (A1B2) Combination Method (A3B2) in the low motor group there is a value of $\mathrm{t} 0=-1,800$ (negative) means the $\mathrm{A} 1 \mathrm{~B} 2$ value is lower A3B2. Thus the average group of students taught by the section method is lower than the group of students who were taught by a combination method for students with low motor skills.

j. Tenth Hypothesis: Differences in the results of outreach skills between the overall method and low motor and the combination method with low motor (A2B2 - A3B2).

The difference between groups t0 (A2B2-A3B2) $=-2,086, \mathrm{p}$-value $=0,043 / 2=0,0215$ $<0,05$ or $\mathrm{H} 0$ rejected means that there is an average difference between groups A2B2 - A3B2.

Furthermore, the average value of the overall method group (A2B2) with the Combination Method (A3B2) in the low motor group there is a value of $t 0=-2,086$ (negative) means that the $\mathrm{A} 2 \mathrm{~B} 2$ value is lower $\mathrm{A} 3 \mathrm{~B} 2$. Thus the average group of students taught by the overall method is lower than the group of students taught by the combination method for students with low motor skills.

After doing a simple hypothesis testing (simple effect) then the next step to analyze Parameter Estimates, the meter estimates can be interpreted to guess the extent to which the level of confidence in a study. The value of estimated parameter values, can be seen in the table below: 
Table 6: Analysis of Estimates Parameters of Jumping Skills with the Treatment of Learning Methods and Motor Ability.

Parameter Estimates

\begin{tabular}{|c|c|c|c|c|c|c|}
\hline \multirow[b]{2}{*}{ Parameter } & \multirow[b]{2}{*}{$\mathrm{B}$} & \multirow[b]{2}{*}{ Std. Error } & \multirow[b]{2}{*}{$t$} & \multirow[b]{2}{*}{ Sig. } & \multicolumn{2}{|c|}{$95 \%$ Confidence Interval } \\
\hline & & & & & Lower Bound & Upper Bound \\
\hline Intercept & 52.025 & 1.379 & 37.717 & .000 & 49.241 & 54.809 \\
\hline$[A=1]$ & -3.511 & 1.951 & -1.800 & .079 & -7.448 & .425 \\
\hline$[A=2]$ & -4.070 & 1.951 & -2.086 & .043 & -8.007 & -.133 \\
\hline$[A=3]$ & $0^{a}$ & & . & & . & . \\
\hline$[B=1]$ & -11.693 & 1.951 & -5.994 & .000 & -15.629 & -7.756 \\
\hline$[B=2]$ & $0^{a}$ & & . & & . & . \\
\hline$[A=1]^{*}[B=1]$ & 22.175 & 2.759 & 8.038 & .000 & 16.608 & 27.742 \\
\hline$[A=1]^{*}[B=2]$ & $0^{a}$ & & & & & . \\
\hline$[A=2]^{*}[B=1]$ & 15.915 & 2.759 & 5.769 & .000 & 10.348 & 21.482 \\
\hline$[A=2]^{*}[B=2]$ & $0^{a}$ & & & & . & \\
\hline$[A=3]^{*}[B=1]$ & $0^{\mathrm{a}}$ & & . & & . & . \\
\hline$[A=3]^{*}[B=2]$ & $0^{\mathrm{a}}$ & & . & & . & \\
\hline
\end{tabular}

a. This parameter is set to zero because it is redundant.

From the table above can be analyzed that the regression model and regression function equation of the influence of learning methods and motor skills can be directly compiled from the table parameter estimates. While the differences between variables and their interaction effects can be seen in the graph below:

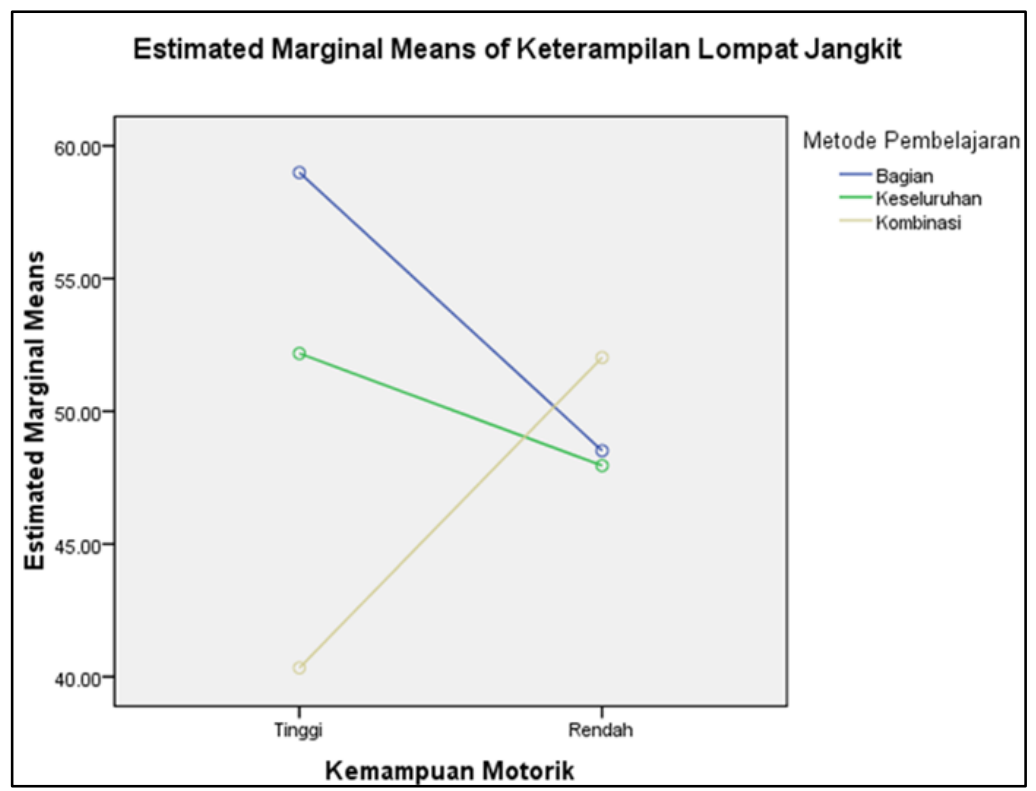

Figure 1. Graph of differences between variables

Further summary of the differences and their interaction effects are presented in the table below:

Table 7. Summary of Hypothesis Test Results

\begin{tabular}{|l|l|c|l|l|l|l|}
\hline No & Hypothesis & $\mathbf{t}_{\mathbf{0}}$ & \multicolumn{1}{|c|}{ Fo } & \multicolumn{1}{|c|}{ p-value } & \multicolumn{2}{|c|}{ Information } \\
\hline 1 & $\mathrm{~A} 1-\mathrm{A} 2$ & $-1,699$ & & $0,048<0,05$ & $\mathrm{H}_{0}$ rejected & $\mathrm{A} 1>\mathrm{A} 2$ \\
\hline 2 & $\mathrm{~A} 1-\mathrm{A} 3$ & $-3,490$ & - & $0,0005<0,05$ & $\mathrm{H}_{0}$ rejected & $\mathrm{A} 1>\mathrm{A} 3$ \\
\hline 3 & $\mathrm{~A} 2-\mathrm{A} 3$ & $-1,791$ & - & $0,0400<0,05$ & $\mathrm{H}_{0}$ rejected & $\mathrm{A} 2>\mathrm{A} 3$ \\
\hline
\end{tabular}




\begin{tabular}{|l|l|l|l|l|l|l|}
\hline 4 & $\begin{array}{l}\text { Interaction } \\
\mathrm{AXB}\end{array}$ & - & 34,349 & $0,000<0,05$ & $\mathrm{H}_{0}$ rejected & Significant \\
\hline 5 & $\mathrm{~A}_{1} \mathrm{~B}_{1}-\mathrm{A}_{2} \mathrm{~B}_{1}$ & 3,496 & - & $0,0005<0,05$ & $\mathrm{H}_{0}$ rejected & $\mathrm{A}_{1} \mathrm{~B}_{1}>\mathrm{A}_{2} \mathrm{~B}_{1}$ \\
\hline 6 & $\mathrm{~A}_{1} \mathrm{~B}_{1}-\mathrm{A}_{3} \mathrm{~B}_{1}$ & 9,568 & - & $0,000<0,05$ & $\mathrm{H}_{0}$ rejected & $\mathrm{A}_{1} \mathrm{~B}_{1}>\mathrm{A}_{3} \mathrm{~B}_{1}$ \\
\hline 7 & $\mathrm{~A}_{2} \mathrm{~B}_{1}-\mathrm{A}_{3} \mathrm{~B}_{1}$ & 6,072 & - & $0,000<0,05$ & $\mathrm{H}_{0}$ rejected & $\mathrm{A}_{2} \mathrm{~B}_{1}>\mathrm{A}_{3} \mathrm{~B}_{1}$ \\
\hline 8 & $\mathrm{~A}_{1} \mathrm{~B}_{2}-\mathrm{A}_{2} \mathrm{~B}_{2}$ & 0,286 & - & $0,388>0,05$ & $\mathrm{H}_{0}$ be accepted & $\mathrm{A}_{1} \mathrm{~B}_{2}<\mathrm{A}_{2} \mathrm{~B}_{2}$ \\
\hline 9 & $\mathrm{~A}_{1} \mathrm{~B}_{2}-\mathrm{A}_{3} \mathrm{~B}_{2}$ & $-1,800$ & - & $0,0395<0,05$ & $\mathrm{H}_{0}$ rejected & $\mathrm{A}_{1} \mathrm{~B}_{2}<\mathrm{A}_{3} \mathrm{~B}_{2}$ \\
\hline 10 & $\mathrm{~A}_{2} \mathrm{~B}_{2}-\mathrm{A}_{3} \mathrm{~B}_{2}$ & $-2,086$ & - & $0,0215>0,05$ & $\mathrm{H}_{0}$ rejected & $\mathrm{A}_{2} \mathrm{~B}_{2}<\mathrm{A}_{3} \mathrm{~B}_{2}$ \\
\hline
\end{tabular}

\section{CONCLUSION}

The Conclusion of This Research Is In Accordance With The Submission of Hypothesis, From The Results of Hypothesis Testing Can Be Drawn Conclusion That: 1) There Is A Difference Between The Part Method With The Overall Method of Skill Jumping on Students Faculty of Teacher Training And Education Physical education University of Riau. 2) There Is A Difference Between The Part Method And The Combination Method of The Jump Skill In The Students of The Faculty of Teacher Training And Education University of Riau. 3) There Is A Difference Between The Overall Method And The Combination Method of The Jump Skill In The Students of The Faculty of Teacher Training And Education University of Riau. 4) There Is An Interaction Effect Between Learning Method And Motor Ability To Jump Skill of Jombang on Faculty of Teacher Training And Education University Student of Riau University. 5) There Are Differences In The Results of The Jump Skill Between The High Motoric Part Method And The High Motoric Overall Method In The Students of The University of Riau. 6) There Is A Difference In The Results of The Transmission Jump Skills Between The High Motoric Part Method And The High Motoric Combination Method For The Students of The University of Riau Examination. 7) There Are Differences In The Results of Outbreak Skills Between The Overall Method With High Motor And High Motoric Combination Methods For Students of The University of Riau. 8) No There Is A Difference (Equal) In The Results of The Jump Skill Between The Low Motoric Part Method And The Low Motorized Overall Method In The Physical education Students. 9) There Are Differences In The Results of Outbreak Skill Between The Low Motoric Part Method And The Low Motoric Combination Method In The Students of The University of Riau. 10) There Are Differences In The Results of Outbreak Skills Between The Overall Method With Low Motor And The Low Motoric Combination Method For the Students of the University of Riau.

\section{REFERENCE}

Abdurrahman Mulyono. (2012). Child Learning Difficulty. Jakarta: PT Rineka Cipta. Achmad Sofyan Hanif. (2015). Sepak Takraw Basic Training. Jakarta: PT RajaGrafindo.

Allen S.J., M.A. King, And M.R. Yeadon. (2013). Trade-Offs Between Horizontal And Vertical Velocities During Triple Jumping And The Effect On Phase Distances. Journal of Biomechanics, UK: Loughborough University.

Dwi Casminto Ariawan and Mugiyo Hartono. (2014). Efforts to Improve Learning Outcomes Jump And Skip Through The Rope Game Merdeka, Journal of Physical Education, Health and Sport 1 (2) Semarang: Concervation University.

Assistant Deputy for Energy Development and Sports Development. (2008). Basic Trainers Training Guidelines and Materials. Deputy for Achievement and Science and Sports Science.

Baechle Thomas R. and Roger W. Earle. (2008). Essentials of Strength Training and Conditioning. United States: Human Kinetics.

Bartlet Roger. (1999). Sport Biomechanics. London: E \& FE Sponge.

Battineli Thomas. (2007). Physique, Fitness, and Performance. Unites States America: CRS Press. Blevins Gayle. (2004). The Softball Coaching Bible. United States: Human Kinetics. 
Bismar Ahmad Rum. (2004). Learning Forehand Drive Results in Game Field "Dissertation, Jakarta: PPs UNJ.

Guidebook for Writing Thesis and Dissertation. (2012). Jakarta: Graduate Program State University of Jakarta.

Bompa O. Tudor and Carlo Buzzichelli. (2014). Periodization Training for Sports, Third Edition. United States: Human Kinetics.

Bordens Kenneth S., Abbott Bruce B. (2014). Research Design and Methods A Process, Approach Ninth Edition. New York: McGraw-Hill Education.

Camerino, Oleguer. Marta Castañer and Teresa M. Anguera. (2012). Mixed Methods Researh in the Movement Sciences. New York.

Çetin Emel, Özgür Özdemir, Yeliz Özdöl. (2013). Biomechanical Evaluation of the Phases of the Triple Jump Take-Off in a Top Female Athlete. 5th World Conference on Educational Sciences - WCES. Turkey: Akdeniz University.

Cook, Gray. 2003) Athletic body in balance. USA: Reebok University.

Dewey Jhon. (2004). Democracy And Education. Indian Edition: First Published.

Douglas Todd. (2009). Cross Country and Track and Field. California: Walnut.

Djumidar. (2004). Basic Athletic Motions in Play. Jakarta: PT RajaGrafindo Persada.

Dlis, Firmansyah. Book of Motor Learning Teaching Materials. Sports Imu, Jakarta State University.

Ega Trisna Rahayu. (2013). Learning Strategy of Physical Education. Bandung: Alfabeta.

Eissa Abeer. (2014). Kinematic analysis last four strides lengths of two different long jump performance, Journal of Human Kinetics volume 40. Egypt: Faculty of Physical Education for Girls, Helwan University.

Firdaus Hidir and Taufiq Hidayat. (2014). Comparison of Part-Method Learning Methods and WholeMethod Methods to Students' Ability to Smash Bolavoli, Ejournal: Unesa.

Freeman, Will. (2015). Track \& Field Coaching Essentials. United States of America: Human Kinetics.

Guthrie, Mark. (2003). Success Train Athletics. Ihsan Madani Library.

Gollhofer, Albert. Taube, Wolfgang and Jens Bo Nielsen. (2012). Routledge Handbook Of Motor Control And Motor Learning. New York: First published by Routledge.

US Hasbunallah. (2004). Effect of Teaching Methods and Motivation on Learning Outcomes Flat Tennis Service Skills. Dissertation Jakarta: PPs UNJ.

Hurlock Elizabet B. Child Development Sixt Edition, Translation. Indonesia: Erlangga Publishers.

Jamaris Martini. (2010). New Orientation In Educational Psychology. Jakarta: Penamas Murni Foundation.

Jerábek Peter. (2003). The Preparation of Junior Athletes For The Combined Events, IAAF, Prague, Czech Republic: New Studies In Athletics.

Karageorghis Costas I. and Peter C. Terry. (2011). Inside Sport Psychology. United State: Human Kinetics.

Kosasih, Engkos. (1984). Sports Techniques and Exercise Programs. Jakarta: Akademika Presindo. Liu Hui, Dewei Mao, Bing Yu. (2015). Effect Of Approach Run Velocity On The Optimal Performance Of The Triple Jump, Elsevier. Shanghai: Shanghai University Of Sport.

Liu Daduo, Rongwei Li. (2011). Training of Physical Education Teachers for Equal Access to Education. Elsevier, International Conference on Environmental Science and Engineering, Singapore: National University of Singapore.

Logan S. W., L. E. Robinson et al. (2011). Getting The Fundamentals Of Movement: A MetaAnalysis Of The Effectiveness Of Motor Skill Interventions In Children, Child: Care, Health And Development, Usa: Blackwell Publishing Ltd.

Lubis Johansyah. (2013). Practical Guide for Preparation of Exercise Program. Jakarta: Raja Grafindo Persada.

Mc Guigan F.J. and Eugene F. Mac Caslin. (1955). Whole and Part Methods in Learning a Perceptual Motor Skill, AJP, USA: University Of IIIinois Pres. 1955

M.J. Irene, Van der Fels et all, The Relationship Between Motor Skills And Cognitive Skills In 4-16 Year Old Typically Developing Children: A systematic review. Journal Of Science and Medicine in Sport: Elsevier.

Maksum Ali. (2012). Research methodology. Surabaya: Unesa Unervirsity Pres. 
Mane Mc. Fred. (2008). The Basics of Athletics. Bandung. Space Printing.

Madjid Abdul. (2014). Integrated Thematic Learning. Bandung: PT Remaja Rosdakarya.

Mohammed Zerf, Mokkedes Moulay Idris Et All. (2015). Influence Technique Vs Ideal Model On Credibility Theory Distributions Ratios: A Case Study Of Triple Jump. European Scientific Journal, University Mostaganem: Laboratory Opaps.

Park Jin-Hoon, Heather Wilde, Charles H. Shea. (2015). Part-Whole Practice of Movement Sequences. Routletge, Texas: Texas A \& M University Department of Health and Kinesiology.

Personal Benny A. (2009). Model of Learning System Design. Jakarta: Dian Rakyat.

Purnomo, Edy and Dapan. (1993). The Basics of Athletic Motion. Yogyakarta: AlfaMedia.

Quinn Paul C., Sherry Burke, And Amy Rush, Part-Whole Perception in Early Infancy Evidence for Perceptual Grouping Produced by Lightness Similarity, Washington and Jefferson College.

Razali. (2006). Learning Outcomes Basketball Skill. Synopsis Diertasi.Jakarta: PPs UNJ.

Ria Lumintuarso. (2013). Sports Coaching Theory. Jakarta: Lankor.

Riduwan, Engkos Acmad Kuncoro. (2012). How to Use and Understand Path Analysis. Bandung: Alfabeta.

Rogers L. Joseph. (2000). USA Track \& Field Coaching Manual. United States: Human Kinetics.

Rusman. (2004). Learning Models. Jakarta: PT RajaGrafindo Persada.

Samsudin. (2014). Media Learning Physical education. Jakarta: litera.

Sanjaya Vienna. (2006). Learning strategies. Jakarta: Kencana PrenadaMedia Group.

Schwelnus Martin P. (2008). The Olympic TexBook of Medicine In Sport. USA: Wiley Blackwell.

Sidik, Dikdik Zafar. (2010). Teaching And Training Athletics. Jakarta: PT Remaja Rosdakarya.

Suherman, Adang. (2001). Athletic Learning, Game Approach and competition for high school / vocational high school students. Jakarta: Director General of Sports, Ministry of National Education.

Sukadianto and Dangsina Muluk. (2011). Introduction to Theory and Methodology of Physical Training. Bandung: Cv. Lubuk Agung.

Sukirno. (2012). The Basics of Athletics and Physical Exercise. Palembang: UNSRI, 2012.

Sumantri Mohamad Syarif. (2016). Learning Strategy. Jakarta: PT RajaGrafindo Persada.

Shah, Hidayat. (2010). Educational Research Methodology A Verifikatif Approach. Yogyakarta: PT.Printing Cemerlang.

Tangkudung, James. (2016). Kinds of Research Methodology Description and Examples. Jakarta: Lensa Media Pustaka Indonesia.

(2006). Sports Coaching, Sports Performance Coaching. Jakarta: Smart Jaya.

Teresa Cattuzzo Maria, et all. (2016). Motor Competence And Health Related Physical Fitness In Youth: A Systematic Review, Elsevier. Australia: Sports Medicine Australia.

Law of the Republic of Indonesia Number 3 of 2005. Regarding the National Sports System.

Widiastuti. (2011). Test and Sport Measurements. Jakarta: PT Bumi Timur Jaya.

William, Edwar H. (2011). Motor Learning and Control. California State University: Wadsworth Cengage Learning.

Wilson Cassie, Scott Simpson, Joseph Hamill. (2009). Movement Coordination Patterns In Triple Jump Training Drills, Routledge. Amherst: University of Massachusetts.

Yu Bing. Horizontal-To-Vertical Velocity Conversion In The Triple Jump Chapel Hill, North Carolina. Usa: Division of Physical Therapy.

Yunyun Yudiana, Herman Subarjah. (2008). Juliantine Tite, Jakarta Training Basics: Open University.

Zafar Sidik. (2010). Teaching And Training Athletics. Jakarta: PT Remaja Rosdakarya. 